\title{
ARTICLE
}

\section{Genetic analysis of mitochondrial ND5 gene of siberian ibex (Capra Sibirica, Pallas, 1776) population in Mongolia}

\author{
Tsenddorj Bilguun ${ }^{1}$, Baatar Delgerzul ${ }^{1}$, Zunduibaatar Unudbayasgalan ${ }^{1}$ \\ Baranz Galbadrakh ${ }^{2}$ and Batsukh Tserendulam ${ }^{1 *}$ \\ ${ }^{1}$ Laboratory of Genetics, Institute of General and Experimental Biology, \\ Mongolian Academy of Sciences, Ulaanbaatar, Mongolia \\ ${ }^{2}$ Mongolia Tour Resort LLC, Ulaanbaatar, Mongolia
}

ARTICLE INFO: Received: 20 Aug, 2019; Accepted: 9 Dec, 2019

\begin{abstract}
The Siberian ibex (Capra sibirica) from Central Asia is believed to be the most ancient species of the genus Capra. In Mongolia, it is distributed in the areas of Mongolian Altai, Gobi-Altai, Dzungaria, Altai, Khan Khuhii, Khoridal Saridag and Ulaan Taiga as well as in the desert and semi-desert steppe zones of Dundgobi and Dornogobi aimags (provinces). In the current study, we investigated the mitochondrial ND5 gene fragments of the Siberian ibex population from different parts of Mongolia. Nine haplotypes, including 6 shared and 3 unique haplotypes were identified among these populations. Furthermore, Tajima's statistics and Fu's statistics did not reveal significant positive value across the population, indicating population decline and balancing selection. In the phylogenetic tree by 9 haplotypes, no separated clusters were generated. In addition, nucleotide diversity was 0.015 , haplotype diversity was 0.86 and the average number of differences in nucleotides was 8.2 in the overall population. These results suggest that genetic diversity across all the populations was low, while haplotype diversity and the average number of differences in nucleotides were high.
\end{abstract}

Keywords: Siberian ibex; mitochondrial ND5 gene; haplotype; population genetic diversity; Capra sibirica;

\section{INTRODUCTION}

Classification of the genus Capra has been a complicated issue in modern taxomony studies of ungulates. In a recent molecular genetic study, the genus Capra contains eight different species: bezoar (C. aegagrus), Alpine ibex ( $C$. ibex), Siberian ibex $(C$. sibirica), Nubian ibex (C. nubiana), Spanish ibex (C. pyrenaica), markhor (C. falconeri), Kuban tur (C. caucasica), and Dagestan tur
(C. cylindricornis). The Siberian ibex from Central Asia is believed to be the most ancient species of the genus Capra [5]. According to the International Union for the Conservation of Nature Red List Categories, this species is listed as Least Concerned at the global level and Near Threatened at the regional level [1]. There are two different subspecies of Siberian ibex (C. sibirica) in terms of geographical 
and genetical characteristics: which are $C$. sibirica and C. s. sakeen [5,6]. In Mongolia, the Siberian ibex is unevenly distributed in the mountainous areas of Mongolia Altai, GobiAltai, Dzungaria, Altai, Khan khuhii, Khoridal Saridag and Ulaan Taiga as well as in desert and semi-desert steppe zones of Dundgobi and Dornogobi aimags [1]. In the early 1980s, Siberian ibex population was estimated at 80.0 thousand in the country, of which around one thousand were found in the red taiga mountains of Khoridal Saridag in Khuvsgul aimag [4].

A 2009 national estimation report of Mongolian mountain ungulates showed that the Siberian ibex was distributed over a total area of $55,985 \mathrm{~km}^{2}$ and the population was estimated as 36.0 thousand in the country [9]. Since ancient times, its population has been declining steadily due to constant tropical hunting, growing acreage of domestic livestock pasture, parasites as well as severe

\section{MATERIALS AND METHODS}

In order to investigate the genetic differentiation among Siberian ibex from different parts of Mongolia, phylogenetic analysis of mitochondrial ND5 gene, which encodes NADH-ubiquinone oxidoreductase chain 5 protein of the electron transport chain, was carried out. Samples of Siberian ibex (Capra sibirica) population in different parts of Mongolia were analyzed. 25 samples from the Altai region, including 8 individuals (sample code: AB1-AB8) from Bayankhongor, 15 individuals (sample code: AH9-AH23) from Khovd, and 2 individuals (sample number: AU24-AU25) from Uvs aimags, were analyzed. Also, 8 samples from the Gobi region and the Khoridal saridag protected are in Khuvsgul, which included 5 individuals (sample code: GI26-GI30) from Ikh nart, Dornogobi and 3 individuals (sample number: KhS31-KhS33) from Khoridal Saridag were analyzed. DNA was isolated from fecal pellets, skin and muscle samples. DNA extraction from fecal pellets was performed using DNA extraction cold winters with heavy snowfall, causing mass deaths $[3,10,13]$. Mitochondrial DNA is one of the most reliable tools for population genetic studies thanks to its relatively high and rapid mutational rate [17]. Also, mitochondrial DNA contains the hypervariable and conserved regions, making them suitable for taxonomic studies [12]. In addition, mitochondrial ND5 gene has been used as a powerful genetic marker to reveal phylogenetic divergence and relationships between and within closely related species in some studies $[8,15]$.

In order to address the issue of protecting endangered species, it is important to study their classification, phylogenetic linkages and population genetic structure at the molecular level. In the current study, we aimed to conduct molecular genetic analysis by mitochondrial ND5 gene of Siberian ibex from different parts of Mongolia.

method from the feces of Caprinae [16].

DNA extraction from other types of tissue samples, such as skin and muscles, was performed using QIAgen tissue kit. Mitochondrial ND5 gene fragment was amplified using primers ND5L (5'-AATAGTTTATCCAGTTGGTCTTAGG-3'), ND5RI (5'-AAGATTTGTTGGAGATCTCAG GTG-3'). PCR amplifications were performed in a total volume of $50 \mu$ l containing 2.5 units of $i T a q^{\mathrm{TM}}$ DNA polymerase, $5 \mu \mathrm{l}$ of 10x PCR buffer, $3 \mu \mathrm{l}$ of $25 \mathrm{mM} \mathrm{MgCl}_{2}, 5 \mu \mathrm{l}$ of $2,5 \mathrm{mM}$ dNTPs, $2 \mu \mathrm{l}$ of $10 \mu \mathrm{M}$ each of the primers and $1 \mu \mathrm{l}$ of genomic DNA. Thermal conditions for PCR are as follows: $94^{\circ} \mathrm{C}$ for 3 min, followed by 35 cycles of $94^{\circ} \mathrm{C}$ for 30 sec, $55^{\circ} \mathrm{C}$ for $30 \mathrm{sec}, 72^{\circ} \mathrm{C}$ for $1 \mathrm{~min}$, and final extension at $72^{\circ} \mathrm{C}$ for $5 \mathrm{~min}$. The PCR products were sequenced in Macrogen Inc, Korea. Sequence data were edited and compiled using Bioedit v.7.2.5 software. Alignment of the sequences was performed by NCBI Blast program (https://blast.ncbi.nlm.nih.gov/Blast. 
cgi). Construction of phylogenetic tree by neighbor-joining method was performed using MEGA v.10 software. Genetic diversity at the molecular level was calculated using DnaSP v.5.2. Statistical analysis of population genetics was performed using Arlequin v. 2.000.

\section{RESULTS AND DISCUSSION}

We have successfully amplified 656 bp fragments of ND5 gene and 554 bp fragments of which was analyzed for the current phylogenetic study. Within ND5 gene fragments, 22 variable sites were identified with transition/transversion ratio of $22: 1$, and 20 parsimony informative sites and 2 singleton sites were among these variable sites. Additionally, constitutions of nitrogenous bases across the populations were C: $42,56 \%$, T: $23.00 \%$, A : $14.6 \%$, G : $19.83 \%$. Nine haplotypes, which includes 6 shared (H1, H2, H3, H4, H7, H9) and 3 unique haplotypes (H5, H6, H8) were detected among 33 individuals of all the populations from Mongolia. Relative frequency of each haplotypes in overall population was between $3 \%$ and $27.3 \%$. The most common haplotype H2 $(27.3 \%)$ was found in 7 individuals of the Siberian ibex population in Bayankhongor aimag, 2 individuals of the Siberian ibex populations in Uvs aimag in the Altai region. The most number of haplotypes (H3, H5, H6, $\mathrm{H} 7, \mathrm{H} 8, \mathrm{H} 9$ ) were detected in 15 individuals of Siberian ibex population in Khovd aimag in the Altai region. In addition, unique haplotypes
$\mathrm{H} 1$ and $\mathrm{H} 4$ were found in 3 individuals of Khoridal Saridag, Khuvsgul and 5 individuals of Ikh Nart, Dornogobi, respectively (Table 1). In the Siberian ibex population in Mongolia, nucleotide diversity presented a low value, while haplotype diversity and average number of differences in nucleotides presented high values (Table 2). For that reason, Altai population, including large numbers of individuals of Siberian ibex populations from different provinces such as Uvs, Khovd, Bayankhongor might have influenced the high value of haplotype diversity and the average number of nucleotide differences due to high number of pairwise differences between individuals arising from a large number of base substitutions. Furthermore, Tajima's statistics' and Fu's statistics did not reveal significant positive value for the populations (Table 2). When positive Tajima's $t$ value is signified, it means low levels of both low and high frequency polymorphisms, indicating population decline and balancing selection [14]. Similarly, positive Fu's Fst indicates a lack of low frequency polymorphism [7]. 


\begin{tabular}{|c|c|c|c|c|c|c|c|c|c|c|}
\hline 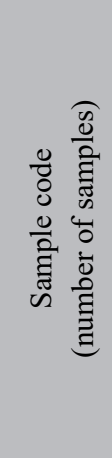 & 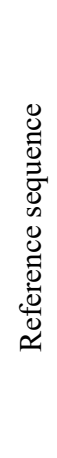 & 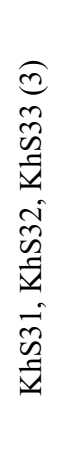 & 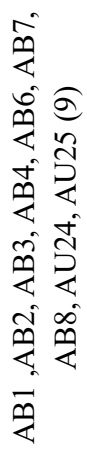 & 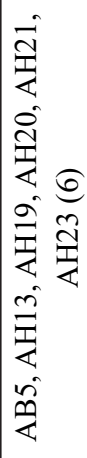 & 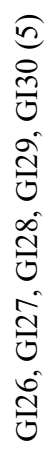 & 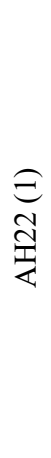 & 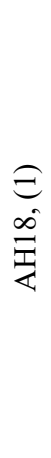 & 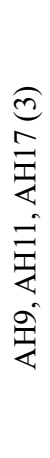 & $\begin{array}{l}\underset{Z}{\Xi} \\
\underset{Z}{Z}\end{array}$ & 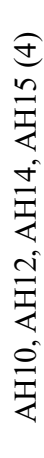 \\
\hline 69ZZI & $U$ & . & . & . & . & $\mapsto$ & & . & . & . \\
\hline દEZZI & $\varangle$ & $\cdot$ & . & . & . & . & $\circlearrowleft$ & . & . & . \\
\hline †0ZZI & 0 & . & . & $\mapsto$ & . & . & . & . & . & $\mapsto$ \\
\hline 00ZZI & $U$ & 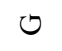 & . & $\varangle$ & 0 & . & . & . & 0 & $\ll$ \\
\hline$\dashv \varepsilon I Z I$ & $\mapsto$ & . & . & $\cdot$ & $\cup$ & . & . & $\cdot$ & $U$ & . \\
\hline ZLOZI & $U$ & . & . & . & $H$ & $\cdot$ & . & $\cdot$ & $\mapsto$ & . \\
\hline LZOZI & $U$ & $H$ & . & $H$ & $H$ & . & & . & $\mapsto$ & H \\
\hline †IOZI & $U$ & . & . & $\mapsto$ & . & $\cdot$ & & $\cdot$ & . & H \\
\hline 666 II & $H$ & . & . & $U$ & . & . & & . & . & $u$ \\
\hline 066 I I & $\varangle$ & . & . & $\circlearrowleft$ & . & . & & $\cdot$ & . & ن \\
\hline 996 II & $U$ & $\mapsto$ & . & . & $\mapsto$ & $\cdot$ & . & . & . & . \\
\hline 096 I I & $U$ & . & . & $\cdot$ & $\mapsto$ & . & & $\cdot$ & $\mapsto$ & . \\
\hline SI6II & $U$ & $\mapsto$ & . & $\mapsto$ & $\mapsto$ & $\cdot$ & & $\cdot$ & $\mapsto$ & $\mapsto$ \\
\hline Z06II & $\mapsto$ & $U$ & . & $U$ & $U$ & . & & . & $U$ & U \\
\hline †68 I I & $U$ & . & . & . & . & . & & . & . & $\mapsto$ \\
\hline I68 I I & $\varangle$ & $\cup$ & . & $\circlearrowleft$ & ن & $\cdot$ & . & . & ن & 0 \\
\hline $9 \angle 8$ I I & $H$ & $U$ & . & $U$ & $U$ & & $U$ & $U$ & $U$ & $U$ \\
\hline $0 \angle 8$ I I & $\circlearrowleft$ & $\varangle$ & . & $\cdot$ & . & $\cdot$ & & $\cdot$ & . & . \\
\hline ऽ98I I & $\circlearrowleft$ & . & . & $\varangle$ & . & $\cdot$ & . & . & . & $\varangle$ \\
\hline 9E8 I I & $U$ & $\cdot$ & . & $H$ & . & . & & $\cdot$ & . & $\mapsto$ \\
\hline SI8I I & ט & . & . & $\varangle$ & . & . & & . & . & $\varangle$ \\
\hline E8L I I & ن & . & . & . & . & . & & . & . & $\varangle$ \\
\hline 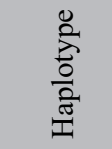 & 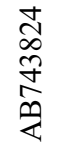 & $\bar{\Xi}$ & I & $\underline{\nexists}$ & $\stackrel{ \pm}{ \pm}$ & 刍 & 矛 & 全 & 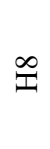 & 9 \\
\hline
\end{tabular}
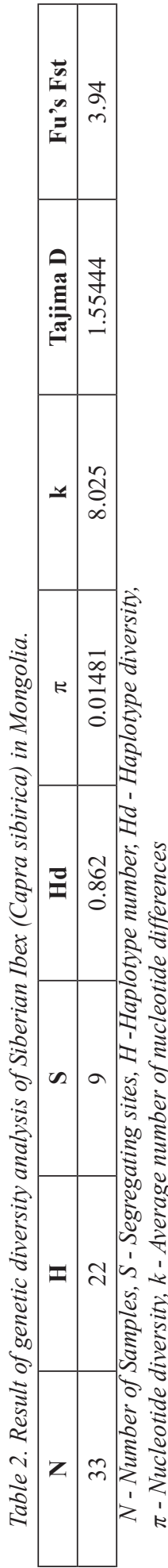

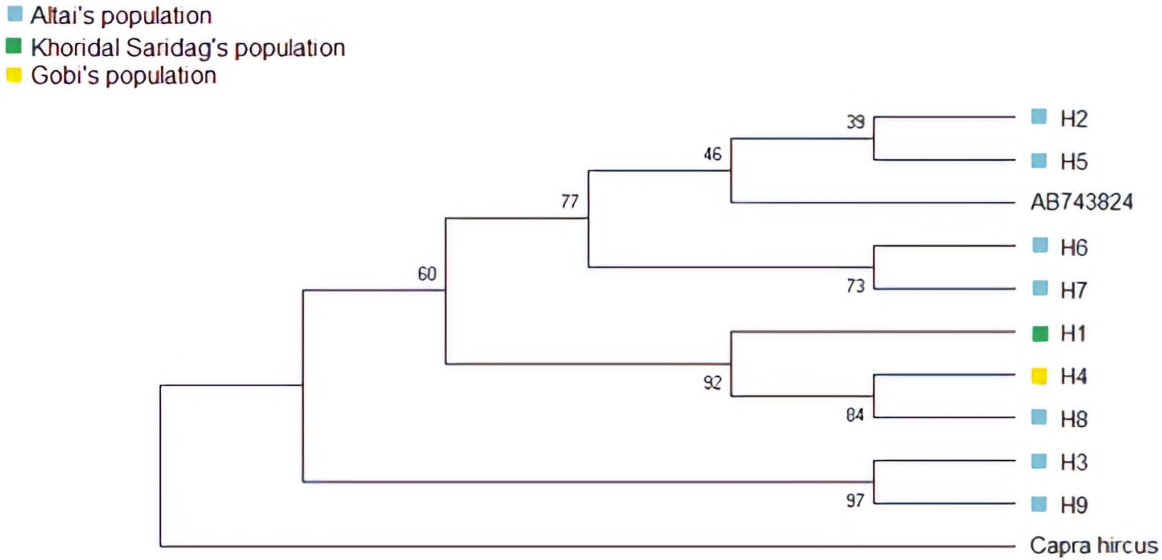

Figure 1. Phylogenetic tree of mitochondrial ND5 haplotypes (554 bp fragment) constructed using Neighbor-joining method. Numbers in nodes indicate bootstrap values $>39$ with 1000 replicates.

In the current study, we conducted the mitochondrial ND5 gene analysis of Siberian ibex (Capra sibirica) population in Mongolia for the first time. We detected a total of 9 haplotypes, $\mathrm{H} 1-\mathrm{H} 9$, and except haplotype $\mathrm{H} 2$, none of which have been registered in the NCBI Genbank. In addition, there are some genetic studies based on the mitochondrial DNA segments, including protein coding regions, to uncover the domestication process of domestic goats (Capra hircus) and their genetic characterization $[2,11]$. As a result of these studies, haplotype $\mathrm{H} 2$, detected from Siberian ibex in Mongolia was registered in the Genbank. Besides, haplotype $\mathrm{H} 2$ was identified as the most common shared haplotype in our

\section{CONCLUSIONS}

In conclusion, genetic diversity across all the populations of Siberian ibex in Mongolia presented a low value, while haplotype diversity and the average number of differences in nucleotides presented high values. Nevertheless, the Altai population, which includesalargenumberofsamples from different provinces, could have influenced the result.

Furthermore, the Siberian ibex population in Khovd aimag of Altai region had the most haplotype diversity. Moreover, both the populations from the protected area of study. So, this could be a broadly distributed haplotype in the Siberian ibex population in Mongolia. Also, the mitochondrial ND5 gene analysis of Siberian ibex is still not widely studied. We, therefore, hope that our data will represent Mongolian Siberian ibex population and contribute to the future population genetic studies of genus Capra based on the mitochondrial ND5 gene. Furthermore, a few samples from the Gobi region and the protected area of Khoridal Saridag was included in this study. Therefore, It is highly recommended to conduct further research on the mitochondrial ND5 gene of Siberian ibex with added number of samples from Gobi and Khoridal Saridag's populations to verify the result.

Khoridal Saridag in Khuvsgul and Ikh Nart, in Dornogobi aimags had their own one unique haplotypes. Thus, the geographical fragmentation might have caused the genetic differentiation across all the populations.

In the future, high sensitive genetic markers such as mitochondrial control region and microsatellite marker studies are recommended in order to obtain more information on the phylogenetic relationships of all the population. 
Acknowledgements: We are grateful to Ts. Janchiv, Kh. Tumennasan, G. Tsogtjargal, Ch. Battsetseg, G. Sergelen, and Ts. Ganbold for their contributions and assistance in the

\section{REFERENCES}

1. E. L. Clark, J. Munkhbat, S. Dulamtseren, J. E. M. Baillie, N., Batsaikhan, R. Samiya, and M., Stubbe, "Mongolian Red List of Mammals. Regional Red List Series", vol. 1, 2006.

2. C. Jia and Z. Wei, "The complete mitochondrial genome of Shaannan White goat (Capra hircus)", Mitochondrial DNA Part A DNA Mapping, Seq. Anal., vol. 27, no. 6, pp. 40864087, 2016.

3. S. Dulamtseren and D. Tsendjav, "Mammals in Mongolia, Animal Kingdom of the Mongolian People's Republic", vol. 2, 1989.

4. R. Dzięciołowski, J. Krupka, X. Bajandelger, and R. Dziedzic, "Argali and Siberian ibex populations in the Khuhsyrh Reserve in Mongolian Altai," Acta Theriol. (Warsz)., vol. 25, no.16, pp. 213-219, 1980.

5. E. Y. Zvychaynaya, "Genetic differentiation of the wild goats (genus Capra) based on the analysis of mitochondrial gene cytochrome b and fragment of nuclear gene SRY", Galemys, vol. 22, pp. 255-276, 2010.

6. K. K. Flerov, "Ungulates of Tadjikistan. Mammals of Tadjikistan”, Moscow. AS SSSR, pp. 93-130, 1935.

7. Y.X. Fu, "Statistical tests of neutrality of mutations against population growth, hitchhiking and background selection", Genetics, vol. 147, no. 2, pp. 915-925, 1997.

8. J. Krzywinski, R. C. Wilkerson, and N. J. Besansky, "Evolution of mitochondrial and ribosomal gene sequences in Anophelinae (Diptera: Culicidae): Implications for phylogeny reconstruction", Mol. Phylogenet. Evol., vol. 18, no.3, pp. 479-487, 2001.

9. B. Lkhagvasuren, S. Amgalanbaatar, and H. Richard, "Nationwide estimation report of Mongolian mountain ungulates", pp. 14, 2010.

10. O. Namnandorj, "Protected areas and animals in the Mongolian People's Republic", 1976.

11. K. Nomura et al., "Domestication Process of the Goat Revealed by an Analysis of the Nearly Complete Mitochondrial Protein-Encoding Genes," PLoS One, vol. 8, no.8, pp. 67773, 2013.

12. C. Simon, F. Frati, A. Beckenbach, B. Crespi, H. Liu, and P. Flook, "Evolution, Weighting, and Phylogenetic Utility of Mitochondrial Gene Sequences and a Compilation of Conserved Polymerase Chain Reaction Primers", Ann. Entomol. Soc. Am., vol. 87, no. 6, pp. 651-701, 1994.

13. V. E. Sokolov, and V. N. Orlov, "Key to mammals of the Mongolian People's Republic", 1980.

14. F. Tajima, "Statistical method for testing the neutral mutation hypothesis by DNA polymorphism," Genetics, vol. 123, no. 3, pp. 585-595. 1989.

15. T. Tserenbataa, R. R. Ramey, O. A. Ryder, T. W. Quinn, and R. P. Reading, "A population genetic comparison of argali sheep (Ovis ammon) in Mongolia using the ND5 gene of mitochondrial DNA; implications for conservation", Mol. Ecol., vol. 13, no. 5, pp. 13331339, 2004.

16. Z. Unudbayasgalan, Ts. Bilguun and B. Tserendulam, "DNA exraction method from the faeces of Caprinae., Proceedings of Institute of General and Experimantal Biology, no. 34, pp. 203-209, 2018.

17. R. M. Zink and G. F. Barrowclough, "Mitochondrial DNA under siege in avian phylogeography,” Molecular Ecology, vol.17, no.9, pp. 2107-2121, 2008. 